\title{
History, Mythology, and 20th Century Latin American Fiction
}

\author{
Jay Corwin $^{1}$
}

The history of the Americas from the colonial period is marked by a large influx of persons from Europe and Africa. Fiction in 20th Century Latin America is marked by ties to the Chronicles and the history of human melding in the Americas, with a natural flow of social and religious syncretism that shapes the unique literary aesthetics of its literatures as may be witnessed in representative authors of genuine merit from different regions of Latin America. [Article copies available for a fee from The Transformative Studies Institute. E-mail address: journal@transformativestudies.org Website: http://www.transformativestudies.org (C2021 by The Transformative Studies Institute. All rights reserved.]

KEYWORDS: Jorge Luis Borges, Gabriel García Márquez, José Vasconcelos, Lydia Cabrera Alejo Carpentier, Jorge Amado, Milan Kundera, Gabriela cravo e canela, colonialism, Emma Zunz, El Aleph, Ficciones, Cien años de soledad, Muiska, Wayuu, Wayunaiki, Popol Vuh, Argentina, Colombia, Cuba,Yoruba tradition, Afro-Caribbean religion, Fray Pedro Simón, Alexander von Humboldt, Milan Kundera, The Yellow Ticket, Milton Sills, Baron Samedi, Zoroastrianism, Conference of the Birds, Achaemenid, Thousand and One Nights, Attar of Nishapur, Ferdowsi, Shahnameh, Macondo, Kikongo language.

It is repetitive and perhaps tiresome to point out that history and literature in Latin America are uniquely intertwined, that modern history of the continents begins in the fictitious or fantastical attributes of some of the earliest chronicles, or in previous combinations of mythology and history that mark the recounting of the Popol Vuh. But it is not

\footnotetext{
${ }^{1}$ Jay Corwin, Ph.D., Senior Lecturer in Spanish. He is the author of La transposición de fuentes indigenas en "Cien años de soledad" (Romance Monographs number 52, 1997), and Gabriel García Márquez (London: Palgrave 2016). He has published analytic essays delving into the indigenous, African and Classical mythological and religious structures in particular writings including those of García Márquez and Jorge Luis Borges, as well as on the psychological framework of Juan Rulfo's Pedro Páramo. Address correspondence to: Jay Corwin, e-mail: jay.corwin@uct.ac.za.
} 